Article

\title{
Impact of Fermentation on the Recovery of Antioxidant Bioactive Compounds from Sea Bass Byproducts
}

\author{
Francisco J. Martí-Quijal ${ }^{1}$ (D), Adrián Tornos ${ }^{1}$, Andrea Príncep ${ }^{1}$, Carlos Luz ${ }^{1}$, Giuseppe Meca ${ }^{1}$, \\ Paola Tedeschi ${ }^{2}$, María-José Ruiz ${ }^{1}$ and Francisco J. Barba ${ }^{1, * \mathbb{D}}$ \\ 1 Nutrition, Food Science and Toxicology Department, Faculty of Pharmacy, Universitat de València, \\ Avda. Vicent Andrés Estellés, s/n, 46100, Burjassot, València, Spain; francisco.j.marti@uv.es (F.J.M.-Q.); \\ tornos@alumni.uv.es (A.T.); anprince@alumni.uv.es (A.P.); carlos.luz@uv.es (C.L.); \\ giuseppe.meca@uv.es (G.M.); m.j.ruiz@uv.es (M.-J.R.) \\ 2 Department of Chemistry and Pharmaceutical Sciences, University of Ferrara, 35 - 44121 Ferrara, Italy; \\ tdspla@unife.it \\ * Correspondence: francisco.barba@uv.es
}

Received: 28 January 2020; Accepted: 13 March 2020; Published: 15 March 2020

\begin{abstract}
The aim of the present research was to obtain antioxidant compounds through the fermentation of fish byproducts by bacteria isolated from sea bass viscera. To that purpose, bacteria from sea bass stomach, intestine, and colon were isolated. With the selected bacteria, growing research was undertaken, fermenting different broths prepared with sea bass meat or byproducts. After the fermentation, the antioxidant activity, phenolic acids, and some proteins were evaluated. The main phenolic acids obtained were DL-3-phenyl-lactic acid and benzoic acid at a maximum concentration of 466 and $314 \mathrm{ppb}$, respectively. The best antioxidant activity was found in the extracts obtained after the fermentation of fish byproducts broth by bacteria isolated from the colon (6502 $\mu \mathrm{M} \mathrm{TE})$ and stomach $(4797 \mu \mathrm{M}$ TE). Moreover, a positive correlation was found between phenolic acids obtained after the fermentation process and the antioxidant activity of the samples. It was also concluded that the lactic acid bacteria isolated from sea bass had an important proteolytic capacity and were able to synthesize phenolic acids with antioxidant capacity. This work has shown the relevance of fermentation as a useful tool to valorize fish byproducts, giving them an added economic value and reducing their environmental impact.
\end{abstract}

Keywords: fermentation; fishing industry byproducts; bioactive peptides; antioxidant activity; phenolic acids

\section{Introduction}

The latest FAO (Food and Agricultural Organization) report, published in 2018, showed an important growth in fish caught over the last few years due to the increased fish population's consumption (from $17.6 \mathrm{~kg}$ per capita in 2007 to $20.3 \mathrm{~kg}$ per capita in 2016) [1].

During the fish production process, several byproducts are produced, representing more than $30 \%$ of fish weight, and in some cases, up to 70\% [2]. Among the different parts of fish that can be considered byproducts, muscle pieces, viscera, thorns, heads, skin, fins, and scales are the most representative [3]. These must be properly managed in order to avoid environmental problems and to maintain the sustainability of the resources. Moreover, it should be noted that since each by-product has a different composition, different alternatives have been evaluated for each of them [4].

For instance, different innovative approaches have been studied in order to valorize fish byproducts due to the environmental problem they represent; for instance, the application of green extraction 
technologies such as ultrasound-assisted extraction, pulsed electric fields, and supercritical fluid extraction to obtain valuable compounds from fish byproducts. These technologies allow the recovery of interesting compounds with the minimum environmental impact, reducing the use of organic solvents, which can be toxic and/or improving the extraction efficiency $[5,6]$.

Fermentation is conventionally used for food preservation, but not so frequently for valorization purposes, as a tool to obtain high added-value compounds. In the food industry, fermentation is considered as any process in which the activity of microorganisms promotes the development of a profitable change in a food or drink [7]. Through fish byproducts, fermentation is possible to obtain quite different high added-value compounds such as bioactive peptides, high-quality oils, or protein hydrolysates, as well as many others like bioplastics, lactic acid, or preservative compounds, which are very useful in food, pharmaceutical or cosmetic industries [8]. For fermentation processes, the main microorganisms used are lactic acid bacteria (LAB), mainly due to their safety, since they are present in a multitude of fermentative processes of food aimed for human consumption, such as dairy products or alcoholic beverages.

The LAB is a group of microorganisms characterized by the production of lactic acid as the main product of carbohydrate fermentation. They are Gram-positive, not sporulated, and have a coralline or bacillary shape [9-11]. These bacteria, through the phosphorylation of carbohydrates, obtain the metabolic energy forming the main metabolite, lactic acid. As the acid is accumulated, the structure of the proteins is modified, as happens with the texture of the product. Such bacteria have been used throughout history for the fermentation of a multitude of foods, producing changes in taste and texture, acting as a preservative, and increasing their shelf life [9,12].

Among the different high added-value compounds obtained from fish byproducts, it is possible to highlight nutrients (e.g., proteins and lipids) as well as bioactive compounds (e.g., polyphenols and bioactive peptides). For instance, during fermentation, LAB play a very important role due to their proteolytic capacity, which allows them to fractionate the proteins into peptides and free amino acids. Generally, small peptides of 3 to 20 amino acids are obtained [13,14]. Some of these peptides have biological activity; therefore, they are considered bioactive peptides [15]. Furthermore, not only are bioactive peptides produced during fermentation, but different phenolic acids have also been found, such as benzoic acid or phenyl-lactic acid, identified in silages inoculated with LAB [16]. These compounds produced by the $\mathrm{LAB}$ are also related to the antimicrobial activity and the antioxidant activity [17].

Sea bass is one of the most produced fish worldwide, but especially in Europe. The main production system is aquaculture, with a production of 165,915 tons in 2016, representing $96 \%$ of the total production [18]. Sea bass culture is mainly focused on the geographical area of the Mediterranean sea, with Turkey, Egypt, Tunisia, Italy, and Spain being the main producers [19]. Due to the new trends in both consumption and commercialization (for example, the sale of frozen fillets), a large number of byproducts are generated during the sea bass production process, which needs to be managed properly, assuming an additional cost for the processing industries [20]. In fact, studies have already been carried out focusing on obtaining high added-value compounds from seabass byproducts $[20,21]$.

Therefore, the present study aims to explore the potential application of fermentation, using LAB isolated from sea bass viscera, in order to valorize sea bass byproducts by obtaining high added-value antioxidant compounds.

\section{Materials and Methods}

\subsection{Samples}

Sea bass samples were purchased from a local supermarket, and they were obtained from the Mediterranean Sea. They were quickly preserved using an ice bath after their death. The same day the samples were obtained, they were eviscerated, and the meat was separated from the byproducts (skin, 
head, tail, thorns, and backbone). Subsequently, all the parts, except the viscera, were frozen until needed for use.

\subsection{Chemicals}

The radical ABTS (2,2' -azino-bis (3-ethylbenzthiazoline-6-sulfonic acid)), Trolox (6-hydroxy-2,5,7,8tetramethylchroman-2-carboxylic acid), Folin-Ciocalteau reagent $1 \mathrm{~N}$, gallic acid, and potassium persulfate $\left(\mathrm{K}_{2} \mathrm{~S}_{2} \mathrm{O}_{8}\right)$ were purchased from Sigma-Aldrich (Steinheim, Germany). The Gram color kit containing crystal violet, Lugol PVP, safranin, and decolorizing solution was purchased from Liofilchem Bacteriology Products (Roseto, Italy). Anaerocult ${ }^{\circledR}$ anaerobic environment system was purchased from Merck (Darmstadt, Germany). The enzyme ammonium persulfate (APS) and tetramethylethylenediamine (TEMED) catalyst used for the polymerization of polyacrylamide gels were obtained from Sigma-Aldrich (St. Louis, USA). Acetonitrile and dithiothreitol (DTT) were purchased from VWR (Leuven, Belgium). The molecular weight pattern 10-250 kDa was obtained from BioRad (Hercules, California). Ethanol $96^{\circ}$ was purchased from GUINAMA S. L. U. (Valencia, Spain).

\subsection{Isolation of Bacteria}

Once the fish samples were eviscerated, those bacteria existing in the digestive tract were isolated. For that purpose, the digestive system of the sea bass samples was separated into three parts, the stomach, small intestine, and colon. Each of these parts was immersed in $200 \mathrm{~mL}$ of Man, Rogosa, and Sharpe broth (MRS Broth, Liofilchem Bacteriology Products, Roseto, Italy) and incubated at $37^{\circ} \mathrm{C}$ for $48 \mathrm{~h}$ under anaerobic conditions, using an Anaerocult ${ }^{\circledR}$ device. Then, serial dilutions were made and growth in Petri dishes with Man, Rogosa, and Sharpe agar (MRS Agar, Liofilchem Bacteriology Products, Roseto, Italy) and incubated at $37^{\circ} \mathrm{C}$ for $48 \mathrm{~h}$. Finally, 8 strains were isolated from each part of the digestive tract, and they were identified using a code about the part of the intestinal tract from where they were isolated ("S" for stomach, " $\mathrm{I}$ " for small intestine, and " $\mathrm{C}$ " for colon) followed each one by a number. All these operations were carried out under sterile conditions in a Telstar MH 100 laminar flow hood (Telstar, Terrassa, Spain).

\subsection{Identification of Bacteria}

To identify the type of bacteria isolated, the colonies were characterized by their characteristic morphologies and their type of fermentation [22,23]. For the analysis of morphological characteristics, shape, surface, edge, and color of the colonies were considered. Moreover, a Gram stain was performed to study the characteristics of the cell membrane and the morphology of the bacteria. The production of acid during fermentation was measured by the decrease of $\mathrm{pH}$.

In order to identify bacteria genetically, a $16 \mathrm{~S}$ rRNA gene sequencing was performed. The identification of isolates was performed using the method described by Chenoll et al. [24] with some modifications. Briefly, the main modification was the primers; in the cited reference, the primers used were 616V and 630R, however, in our case, we used 616V and 699R. The DNA culture was extracted using the high pure PCR template preparation kit (Roche). The 16S rRNA sequence was amplified and sequenced using an Applied Biosystems ABI PRISM BigDye terminator cycle sequencing ready reaction kit (Foster City, CA, USA). The DNA templates were amplified by PCR using the universal primers amplifying a 1000 bp region of the 16S rRNA gene; 616V: 5' -AGAGTTTGATYMTGGCTCAG-3' for the forward primer and 699R: 5'-RGGGTTGCGCTCGTT-3' for the reverse primer. The 616V and 699R primers, Taq DNA polymerase, and dNTP mix were obtained from Thermo Fisher Scientific (Waltham, MA, USA). The DNA templates were amplified by initial denaturation at $94{ }^{\circ} \mathrm{C}$ for $10 \mathrm{~min}$, followed by 40 cycles of denaturation at $94{ }^{\circ} \mathrm{C}$ for $1 \mathrm{~min}$, annealing at $55^{\circ} \mathrm{C}$ for $1 \mathrm{~min}$, extension at $72{ }^{\circ} \mathrm{C}$ for $1 \mathrm{~min}$ and a final extension at $72{ }^{\circ} \mathrm{C}$ for $10 \mathrm{~min}$. The integrity of the PCR products was assayed by the development of single bands following electrophoresis for $1 \mathrm{~h}$ at $100 \mathrm{~V}$ in $2 \%(\mathrm{w} / \mathrm{v}$ ) agarose gels in Tris-borate EDTA buffer. Amplicons were purified using the commercial Metabion $\mathrm{GmbH}$ mi-PCR purification kit (Planegg, Germany), followed by sequencing reactions using the BigDye 
terminator v3.1 cycle sequencing kit (Applied Biosystems), premixed format. The resulting sequences were automatically aligned and inspected visually and then compared with the on-line tool BLAST [25]. The strain was identified based on the highest scores. The isolated and identified bacteria are kept at the Department of Preventive Medicine and Public Health (Faculty of Pharmacy, Universitat de València) and are available to any research group which is interested in working with them.

\subsection{Elaboration of Fish Meat and Fish Byproducts Broths}

Four different growth broths were elaborated: waste broth (WB; fish byproducts), meat broth (MB; fish fillets), waste broth $2 \%$ glucose (WBG; fish byproducts $+2 \%$ glucose), and meat broth $2 \%$ glucose (MBG; fish fillets $+2 \%$ glucose).

The procedure carried out to prepare the broths was the same in all of them. Firstly, an Oster 4655 crusher (London, United Kingdom) was used for crushing fish byproducts or meat, following a ratio of 1:3 (w/v) with water. Subsequently, the broths were centrifuged (4000 rpm, $15 \mathrm{~min})$ using an Eppendorf 5810R centrifuge (Hamburg, Germany). The supernatants were poured into $1 \mathrm{~L}$ bottles, and $2 \%$ glucose was added to the corresponding broths. Then, they were pasteurized using an SBS30 bath (Staffordshire, United Kingdom) at $85^{\circ} \mathrm{C}$ for $20 \mathrm{~min}$ [26]. Once pasteurized, they were again centrifuged at $4000 \mathrm{rpm}$ for $15 \mathrm{~min}$. The different broths were frozen until use.

\subsection{Fermentation}

To carry out the fermentation process, $2 \mathrm{~mL}$ of exponentially growing bacteria $\left(37^{\circ} \mathrm{C}\right.$ for $12 \mathrm{~h}$ ) were inoculated in $100 \mathrm{~mL}$ MRS Broth at a final concentration of $10^{7} \mathrm{CFU} / \mathrm{mL}$ and incubated in different tubes at $37^{\circ} \mathrm{C}$ for 24,48 , and $72 \mathrm{~h}$. To verify that the fermentation was performed appropriately, the $\mathrm{pH}$ was measured, and the bacterial load count was carried out every $24 \mathrm{~h}$.

After the incubation period, the tubes were centrifuged in an Eppendorf 5810R centrifuge (Hamburg, Germany) at $4000 \mathrm{rpm}$ for $10 \mathrm{~min}$. The supernatants, once cleaned of cells, were frozen at $-20{ }^{\circ} \mathrm{C}$.

\subsection{SDS-PAGE Electrophoresis}

In order to evaluate the different sizes of fish protein residues after $72 \mathrm{~h}$ fermentation, SDS-PAGE electrophoresis was performed according to the method previously described [27].

\subsection{Extraction and Identification of Phenolic Acids}

To determine the phenolic acids produced by the LAB, the method described by Denardi-Souza et al. [28] was carried out. For that purpose, LC-ESI-qTOF-MS was used.

The equipment used for the analysis consisted of LC Agilent 1200 (California, USA) chromatography. The column used was a Gemini C18 $50 \times 2 \mathrm{~mm}$, with $100 \AA$ and a particle size of $3 \mu \mathrm{m}$ (Phenomenex). The mobile phases used were water as solvent $\mathrm{A}$ and acetonitrile as solvent $\mathrm{B}$, both acidified with $0.1 \%$ formic acid. The chosen elution gradient was $0 \mathrm{~min}, 5 \% \mathrm{~B} ; 30 \mathrm{~min}$ $95 \% \mathrm{~B} ; 35 \mathrm{~min}, 5 \% \mathrm{~B}$, at a flow rate of $0.3 \mathrm{~mL} / \mathrm{min}$. Finally, the volume injected was $20 \mu \mathrm{L}$, and the column equilibrated 3 min before the next analysis.

Mass spectrometry was performed with an Agilent ultra high definition accurate mass Q-TOF-MS 6540, equipped with Agilent dual jet stream (Dual AJS ESI) electrospray ionization source. It was programmed in the negative ionization mode with the following conditions: drying gas flow at $8 \mathrm{~L} / \mathrm{min}$, drying gas temperature at $350{ }^{\circ} \mathrm{C}$, nebulizer pressure at $30 \mathrm{psi}$, capillary voltage at $3.5 \mathrm{kV}$, voltage fragmentor at $175 \mathrm{~V}$, and scan range from 20 to $380 \mathrm{~m} / \mathrm{z}$. Collision energies of 10, 20, and 40 eV were used for the targeted MS/MS experiments. Finally, integration and data elaboration were managed using the Masshunter qualitative analysis B.08.00 software. 


\subsection{Antioxidant Activity}

To determine the total antioxidant capacity, the TEAC (Trolox equivalent antioxidant capacity) assay was used as previously described [29].

Briefly, $25 \mathrm{~mL}$ of ABTS $(7 \mathrm{mM})$ was mixed with $440 \mu \mathrm{L}$ of $\mathrm{K}_{2} \mathrm{~S}_{2} \mathrm{O}_{8}(140 \mathrm{mM})$ and kept at room temperature for $12-16 \mathrm{~h}$ in darkness to obtain the radical ABTS $\bullet^{+}$. This solution was diluted $1 / 100$ in ethanol in order to obtain a working solution with an absorbance of $0.700 \pm 0.020$ measured at $734 \mathrm{~nm}\left(\mathrm{~A}_{0}\right.$, initial absorbance). Then, $100 \mu \mathrm{L}$ of the appropriately diluted extracts were added, and the absorbance was measured at $3 \mathrm{~min}\left(\mathrm{~A}_{\mathrm{f}}\right)$ in a Perkin-Elmer UV/Vis Lambda 2 spectrophotometer (Perkin-Elmer, Jügesheim, Germany). The measurements were made in triplicate. The percentage of inhibition (\% Inhibition) was calculated using the following equation (1);

$$
\% \text { Inhibition }=\left(1-\frac{A_{f}}{A_{0}}\right) \times 100
$$

In order to obtain the antioxidant capacity, a standard curve was first established with Trolox, and the percentage of inhibition of the samples was interpolated. The results were expressed as micromolar Trolox equivalent ( $\mu \mathrm{M} \mathrm{TE})$.

\subsection{Statistical Analysis}

The statistical analysis was performed using the InfoStat ${ }^{\circledR}$ software version 2018. All experiments were performed in triplicate, and the differences between the groups were analyzed using a one-way analysis of the variance (ANOVA) followed by the Tukey HSD post-test for multiple comparisons. The level of significance considered as $p \leq 0.05$.

The correlations were established using the StatAdvisor ${ }^{\circledR}$ software version 2018 and Pearson's test. The range of correlation coefficients ranged from -1 to +1 , and they measured the strength of the linear relationship between the variables. $p$ values $\leq 0.05$ indicate correlations significantly different from zero, with a confidence level of $95.0 \%$.

\section{Results and Discussion}

\subsection{Isolation and Identification of Bacteria}

Although 64 different strains were initially isolated ( 8 from each part of the digestive tract of different sea bass fishes), only 30 were finally obtained (7 from the stomach, 7 from the intestine and 16 from the colon), due to the rest having either stopped growing or not showing adequate growth. After the strains were correctly isolated and identified, different aspects of the colonies were analyzed. All had a white, circular shape and were opaque. In addition, they did not present any type of pigment, which fits perfectly with the description of LAB provided by Astuti [22].

Subsequently, a Gram stain of each of the isolated colonies was performed, and, as a result, Gram-positive cocci and bacilli were obtained. After the first identification of the morphology, different bacteria from different parts were selected and fermented with two types of broths to see if the $\mathrm{pH}$ was modified. The $\mathrm{pH}$ decreased independently of the colonies studied as fermentation time increased, whereas this effect was not observed in the controls (Table 1).

With the results obtained after carrying out the above-mentioned tests, it could be concluded that the isolated bacteria could belong to the LAB family since their morphology was identical to the LAB, the compounds produced during the fermentation were acidic and promoted a decrease in $\mathrm{pH}$, and also because they were isolated in MRS medium, which is suitable for LAB growth.

However, in order to obtain a clear bacteria identification, a 16S rRNA gene sequencing was performed for four of these bacteria. The results obtained showed that isolated bacteria were Lactobacillus plantarum, concluding that the isolated bacteria were LAB. For instance, several authors have isolated lactic bacteria (mainly Streptococcus, Enterococcus, Lactobacillus, Carnobacterium, and Lactococcus genera) 
from the intestinal tract of different types of fish [11,30,31], and the stomach, intestine, and gills using the same method [32].

Table 1. $\mathrm{pH}$ results during fermentation.

\begin{tabular}{ccccc}
\hline Sample & $\mathbf{0 h}$ & $\mathbf{2 4} \mathbf{h}$ & $\mathbf{4 8} \mathbf{h}$ & $\mathbf{7 2} \mathbf{h}$ \\
\hline MB CONTROL & 6.97 & 6.98 & 6.89 & 6.84 \\
WB CONTROL & 6.87 & 6.80 & 6.76 & 6.63 \\
S3 MB & 6.97 & 6.36 & 6.01 & 5.71 \\
S3 WB & 6.87 & 6.15 & 5.92 & 5.70 \\
S4 MB & 6.97 & 5.70 & 3.99 & 3.83 \\
S4 WB & 6.87 & 5.55 & 3.80 & 3.73 \\
S6 MB & 6.97 & 6.34 & 5.93 & 5.69 \\
S6 WB & 6.87 & 6.27 & 5.81 & 5.53 \\
S7 MB & 6.97 & 6.75 & 4.45 & 4.73 \\
S7 WB & 6.87 & 6.67 & 5.10 & 3.74 \\
I1 MB & 6.97 & 6.60 & 5.99 & 5.68 \\
I1 WB & 6.87 & 6.43 & 5.80 & 5.55 \\
C7 MB & 6.97 & 5.54 & 4.45 & 4.30 \\
C7 WB & 6.87 & 5.45 & 5.10 & 5.23 \\
C8 MB & 6.97 & 6.45 & 6.12 & 4.54 \\
C8 WB & 6.87 & 6.30 & 4.38 & 4.35 \\
\hline
\end{tabular}

$\mathrm{MB}$, meat broth; $\mathrm{WB}$, waste broth; $\mathrm{S}$, bacteria from stomach; I, bacteria from small intestine; $\mathrm{C}$, bacteria from colon.

\subsection{Fermentation}

Regarding the results of the bacterial load test performed to choose the best culture broth, as can be seen in Table 2, there were no statistically significant differences $(p>0.05)$ between the broths containing $2 \%$ glucose (MBG and WBG) and those that do not (MB and WB).

Table 2. Bacterial load (logarithms) from the stomach, intestine, and colon.

\begin{tabular}{ccccc}
\hline Heading & MB & MBG & WB & WBG \\
\hline Stomach bacteria & $9.96 \pm 1.63^{\mathrm{A}}$ & $10.23 \pm 1.62^{\mathrm{A}}$ & $9.97 \pm 2.13^{\mathrm{B}}$ & $9.93 \pm 1.62^{\mathrm{B}}$ \\
Intestine bacteria & $8.92 \pm 3.84^{\mathrm{A}}$ & $7.85 \pm 1.69^{\mathrm{A}}$ & $9.21 \pm 1.80^{\mathrm{B}}$ & $9.36 \pm 2.01^{\mathrm{B}}$ \\
Colon bacteria & $10.35 \pm 1.30^{\mathrm{A}}$ & $10.47 \pm 2.53^{\mathrm{A}}$ & $10.19 \pm 2.69^{\mathrm{B}}$ & $10.84 \pm 1.32^{\mathrm{B}}$ \\
\hline
\end{tabular}

Different letters in the same column mean statistically significant differences ( $p \leq 0.05)$. MB, meat broth; MBG, meat broth with $2 \%$ glucose; WB, waste broth; WBG, waste broth with $2 \%$ glucose.

According to Table 2, there were no significant differences between any of the broths tested. However, it was finally decided to use those samples containing $2 \%$ glucose in order to provide more carbohydrates to the broth, and thus ensuring bacterial growth.

\subsection{Electrophoresis}

Regarding the results obtained after using the electrophoresis, a great difference was observed in the protein profile between the different fermented broths. The fermented MBGs had higher protein concentration and molecular weight than the WBG, which showed a reduced protein concentration and lower molecular weight (10-15 kDa). Figure 1 shows the proteolytic activity of different bacteria strains on the WBG. As can be seen in Figure 1, the strains S4, S7, and C8 showed hydrolysis of the proteins present in the WBG. However, the rest of the fermented WBGs did not show great differences compared to the control. 


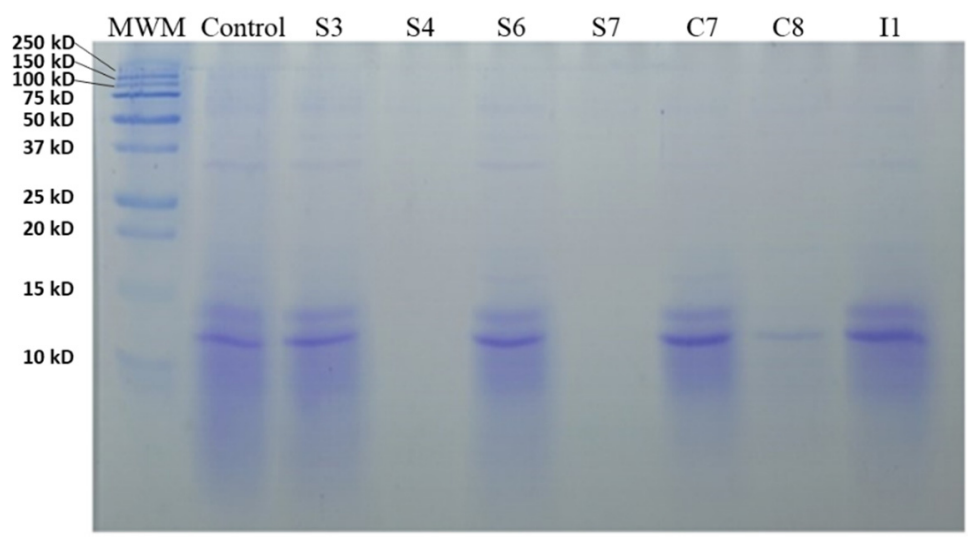

Figure 1. SDS-PAGE analysis of fermented waste broth with $2 \%$ glucose with different isolated bacteria; MWM, molecular weight marker.

Regarding the MBG (Figure 2), there was greater proteolysis when strains S4, C7, and C8 were used; thus, promoting the hydrolysis of proteins of high molecular weight $(20-250 \mathrm{kDa})$. The rest of the strains had a similar amount of protein, like the control, despite the fermentation process.

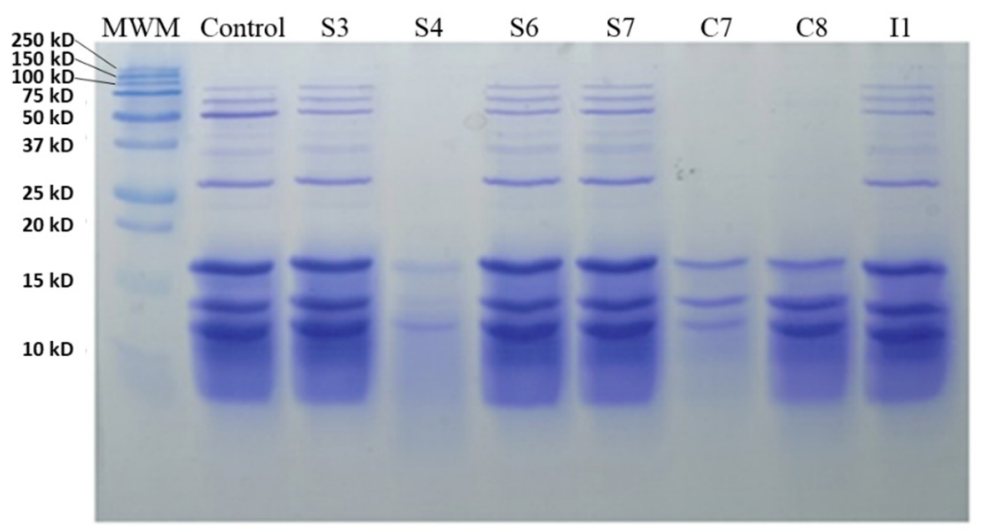

Figure 2. SDS-PAGE analysis of fermented meat broth with $2 \%$ glucose with different isolated bacteria; MWM, molecular weight marker.

The results obtained in our study were similar to previous works carried out by other authors. For instance, Altinelataman et al. [26] analyzed the protein profile of sea bass and sea bream muscle hydrolysates by SDS-PAGE. These authors concluded that the peptides often appeared to be included within larger fragments because incomplete hydrolysis occurred. In the same study, the authors were able to identify different proteins such as parvalbumin beta-2 $(15 \mathrm{kD})$ or triosephosphate isomerase B (24-26 kD), which is in accordance with our results.

\subsection{Phenolic Acids}

Two phenolic acids, DL-3-phenyllactic acid, and benzoic acid, were isolated from the broths used in this study resulting from the fermentation process. The results showed an increase in the content of these compounds was obtained during the fermentation time, thus, it was demonstrated that these acids were products of fermentation since these compounds were not found in any of the control samples.

As shown in Table 3, the bacteria isolated from the stomach produced the greatest amount of phenolic acids in MBG and WBG, being the predominant compound DL-3-phenyllactic acid, reaching up to $467 \mathrm{ppb}$ when the S7 strain was used. Benzoic acid was also found, with lower values, up to $314 \mathrm{ppb}$ when the $\mathrm{S} 4$ strain was used. Both phenolic acids increase when fermentation time increases. 
Table 3. Phenolic acids in fermented and control samples.

\begin{tabular}{|c|c|c|c|c|c|c|c|}
\hline \multicolumn{2}{|c|}{ Samples } & \multicolumn{3}{|c|}{ DL-3-phenyllactic Acid } & \multicolumn{3}{|c|}{ Benzoic Acid } \\
\hline & & $24 \mathrm{~h}$ & $48 \mathrm{~h}$ & $72 \mathrm{~h}$ & $24 \mathrm{~h}$ & $48 \mathrm{~h}$ & $72 \mathrm{~h}$ \\
\hline \multirow{8}{*}{ 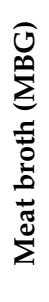 } & CONTROL & nd & nd & nd & nd & nd & nd \\
\hline & S3 & $11.4 \pm 2.5^{b}$ & $30.9 \pm 1.2^{\mathrm{d}}$ & $33.0 \pm 1.1^{b}$ & $52.8 \pm 4.3^{c}$ & $101.0 \pm 2.5^{\mathrm{f}}$ & $166.4 \pm 2.2^{\mathrm{e}}$ \\
\hline & S4 & nd & $12.7 \pm 0.4^{b}$ & $29.4 \pm 0.7^{b}$ & $76.4 \pm 3.6^{d}$ & $179.8 \pm 3.4 \mathrm{~g}$ & $314.2 \pm 5.7^{f}$ \\
\hline & S6 & $64.1 \pm 1.9^{\mathrm{d}}$ & $109.5 \pm 3.5^{\mathrm{g}}$ & $289.9 \pm 1.6^{\mathrm{f}}$ & $29.0 \pm 4.2^{b}$ & $19.4 \pm 0.6^{b}$ & $12.9 \pm 0.9^{b}$ \\
\hline & S7 & $21.0 \pm 1.5^{c}$ & $192.9 \pm 2.3^{h}$ & $466.7 \pm 3.5^{g}$ & $35.0 \pm 0.7^{b}$ & $51.7 \pm 2.3^{\mathrm{d}}$ & $51.0 \pm 2.4^{\mathrm{c}}$ \\
\hline & I1 & $10.5 \pm 1.2^{b}$ & $20.7 \pm 2.2^{c}$ & $163.0 \pm 4.1^{\mathrm{e}}$ & nd & $66.5 \pm 2.3^{\mathrm{e}}$ & $13.2 \pm 0.8^{b}$ \\
\hline & $\mathrm{C} 7$ & $9.6 \pm 2.6^{b}$ & $38.4 \pm 2.3^{e}$ & $76.7 \pm 1.4^{\mathrm{d}}$ & $0.7 \pm 0.3^{\mathrm{a}}$ & $4.5 \pm 0.8^{\mathrm{a}}$ & $4.6 \pm 0.2^{\mathrm{a}}$ \\
\hline & $\mathrm{C} 8$ & $20.8 \pm 1.2^{c}$ & $49.7 \pm 2.1^{f}$ & $51.7 \pm 1.1^{\mathrm{c}}$ & $4.7 \pm 0.9^{a}$ & $28.0 \pm 2.2^{c}$ & $92.1 \pm 2.3^{\mathrm{d}}$ \\
\hline \multirow{8}{*}{ 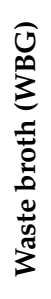 } & CONTROL & nd & nd & nd & nd & nd & nd \\
\hline & S3 & $21.9 \pm 1.5^{b}$ & $145.4 \pm 4.2^{\mathrm{d}}$ & $138.4 \pm 4.2^{\mathrm{e}}$ & $172.7 \pm 2.6^{f}$ & $59.5 \pm 4.3^{c}$ & $74.8 \pm 6.7^{\mathrm{e}}$ \\
\hline & S4 & $23.1 \pm 1.1^{b, c}$ & $186.4 \pm 2.4^{\mathrm{e}}$ & $71.8 \pm 2.2^{\mathrm{c}}$ & $117.9 \pm 4.3^{\mathrm{e}}$ & $101.8 \pm 3.3^{c}$ & $48.7 \pm 1.1^{\mathrm{d}}$ \\
\hline & S6 & $26.5 \pm 2.7^{c, d}$ & $22.6 \pm 3.6^{b}$ & $20.1 \pm 1.2^{b}$ & $89.5 \pm 4.7^{c}$ & $82.3 \pm 5.2^{c}$ & $92.2 \pm 6.6^{f}$ \\
\hline & S7 & $21.0 \pm 1.1^{b}$ & $19.7 \pm 5.4^{b}$ & $146.7 \pm 3.2^{f}$ & $101.9 \pm 2.5^{\mathrm{d}}$ & $7.6 \pm 1.6^{a, b}$ & $17.5 \pm 4.4^{b}$ \\
\hline & I1 & $30.7 \pm 2.1^{\mathrm{d}}$ & $160.1 \pm 1.5^{\mathrm{d}}$ & $175.0 \pm 3.3^{g}$ & $88.9 \pm 5.2^{\mathrm{c}}$ & $64.7 \pm 3.3^{c}$ & $21.3 \pm 3.1^{b, c}$ \\
\hline & $\mathrm{C} 7$ & $53.8 \pm 1.3^{\mathrm{e}}$ & $65.8 \pm 2.3^{e, c}$ & $81.5 \pm 0.6^{\mathrm{d}}$ & $44.8 \pm 2.2^{b}$ & $22.8 \pm 2.1^{\mathrm{b}}$ & $25.4 \pm 3.2^{b, c}$ \\
\hline & $\mathrm{C} 8$ & $28.0 \pm 1.2^{\mathrm{d}}$ & $80.5 \pm 3.3^{c}$ & $198.2 \pm 4.5^{\mathrm{h}}$ & $460.5 \pm 3.3^{g}$ & $120.0 \pm 5.2^{\mathrm{d}}$ & $32.5 \pm 4.1^{\mathrm{c}}$ \\
\hline
\end{tabular}

Results expressed in ppb, parts per billion. Different letters in the same column mean statistically significant differences $(p \leq 0.05)$; nd, not detected.

Other authors have studied the production of phenolic acids after using the fermentation process in different matrices. For example, Lavermicocca et al. [33] observed an important amount of DL-3-phenyllactic acid after fermentation with 9 LAB in MRS. On the other hand, the study by Lau and Liong [34] concluded that the concentrations of the acids produced by the LAB species differed according to the strain studied. Urbiene and Leskauskaite [35] investigated the formation of benzoic, sorbic, and nucleic acids during fermentation with LAB. They found concentrations up to $14-23 \mathrm{mg} / \mathrm{kg}$ of benzoic acid in the milk fermented by LAB.

In the study conducted by Quattrini et al. [36], the potential of 25 strains of Lactobacillus plantarum was explored. They were able to produce 1,2-dihydroxybenzene, benzoic acid, p-hydroxyphenyllactic acid, and DL-3-phenyllactic, which agree with our results. Ramos et al. [37] studied strains of Lactobacillus plantarum, finding that these strains produced mevalonolactone, 5-methyl-hydantoin, and benzoic acid. Moreover, Yu et al. [38] examined the use of Lactobacillus rhamnosus, Lactobacillus paracasei, and Streptococcus thermophilus at different incubation temperatures and optimized the production of benzoic acid.

\subsection{Antioxidant Activity}

Table 4 shows the results of the antioxidant activity of the fermented samples. As can be seen, the results are quite different, reaching the highest antioxidant activity after using a fermentation process of $24 \mathrm{~h}$. The only sample that achieved significant differences in antioxidant activity respect to control was $\mathrm{C} 8$. The $\mathrm{C} 7$ sample, and all those from the stomach (S), reached values with a large difference compared to control after $48 \mathrm{~h}$ of fermentation. A similar response was observed for stomach samples (S) after $72 \mathrm{~h}$. Considering the results obtained, it can be affirmed that, in the case of MBG, the samples with the highest antioxidant activity are those that have been fermented by bacteria from the stomach (Table 4). 
Table 4. Antioxidant activity ( $\mu \mathrm{M}$ Trolox equivalent) of the meat broth with $2 \%$ glucose fermented by the selected bacteria at $37^{\circ} \mathrm{C}$ for 24,48 , and $72 \mathrm{~h}$.

\begin{tabular}{cccc}
\hline Sample & $\mathbf{2 4} \mathbf{h}$ & $\mathbf{4 8} \mathbf{h}$ & $\mathbf{7 2 ~ \mathbf { ~ }}$ \\
\hline Control & $793.12 \pm 63.54^{\mathrm{a}}$ & $463.70 \pm 22.12^{\mathrm{a}}$ & $452.84 \pm 21.68^{\mathrm{a}}$ \\
S3 & $865.39 \pm 44.62^{\mathrm{a}, \mathrm{b}}$ & $1106.30 \pm 21.36^{\mathrm{e}}$ & $1073.35 \pm 37.11^{\mathrm{d}}$ \\
S4 & $987.57 \pm 14,66^{\mathrm{a}, \mathrm{b}, \mathrm{c}}$ & $1030.92 \pm 10.28^{\mathrm{e}}$ & $882.42 \pm 20.72^{\mathrm{c}}$ \\
S6 & $831.32 \pm 78.12^{\mathrm{a}, \mathrm{b}}$ & $815.63 \pm 47.03^{\mathrm{d}}$ & $683.97 \pm 112.19^{\mathrm{b}}$ \\
S7 & $845.94 \pm 66.62^{\mathrm{a}, \mathrm{b}}$ & $664.60 \pm 20.43^{\mathrm{c}}$ & $601.92 \pm 7.36^{\mathrm{b}}$ \\
I1 & $1079.94 \pm 45.08^{\mathrm{c}, \mathrm{d}}$ & $442.33 \pm 23.39^{\mathrm{a}}$ & $645.77 \pm 26.70^{\mathrm{b}}$ \\
C7 & $1021.60 \pm 93.76^{\mathrm{b}, \mathrm{c}}$ & $570.56 \pm 18^{\mathrm{b}}$ & $436.43 \pm 28.88^{\mathrm{a}}$ \\
C8 & $1231.60 \pm 118.03^{\mathrm{d}}$ & $624.76 \pm 44.78^{\mathrm{b}, \mathrm{c}}$ & $651.49 \pm 46.72^{\mathrm{b}}$ \\
\hline
\end{tabular}

Different letters in the same column mean statistically significant differences $(p \leq 0.05)$ from control samples.

As for the samples obtained from the WBG (Table 5), the strains S3 and I1 stand out and showed a greater antioxidant activity compared to the control (without bacteria) samples. With this broth, the highest antioxidant activity was reached at $48 \mathrm{~h}$. The $\mathrm{C} 8$ strain showed the highest activity of all samples after $72 \mathrm{~h}$ of fermentation. Once again, bacteria from the stomach are, in general, the ones with the greatest antioxidant activity.

Table 5. Antioxidant activity ( $\mu \mathrm{M}$ Trolox equivalent) of waste broth with $2 \%$ glucose fermented by the selected bacteria at $37^{\circ} \mathrm{C}$ for 24,48 , and $72 \mathrm{~h}$.

\begin{tabular}{cccc}
\hline Sample & $\mathbf{2 4} \mathbf{h}$ & $\mathbf{4 8} \mathbf{h}$ & $\mathbf{7 2 ~ \mathbf { ~ }}$ \\
\hline Control & $1160.11 \pm 95.75^{\mathrm{a}}$ & $1968.92 \pm 104.04^{\mathrm{b}}$ & $1629.99 \pm 63.39^{\mathrm{bc}}$ \\
S3 & $2559.33 \pm 271.05^{\mathrm{c}}$ & $4797.41 \pm 407.22^{\mathrm{e}}$ & $2370.39 \pm 248.17^{\mathrm{d}}$ \\
S4 & $1474.13 \pm 5.29^{\mathrm{a}, \mathrm{b}}$ & $3726.24 \pm 64.46^{\mathrm{d}}$ & $1355.54 \pm 44.41^{\mathrm{b}}$ \\
S6 & $1218.92 \pm 47.74^{\mathrm{a}}$ & $1189.09 \pm 13.98^{\mathrm{a}}$ & $1085.19 \pm 22.04^{\mathrm{a}, \mathrm{b}}$ \\
S7 & $1243.28 \pm 74.25^{\mathrm{a}}$ & $3058.00 \pm 71.93^{\mathrm{c}}$ & $1223.49 \pm 75.49^{\mathrm{a}, \mathrm{b}}$ \\
I1 & $2228.97 \pm 129.09^{\mathrm{c}}$ & $2256.52 \pm 54.28^{\mathrm{b}}$ & $2130.25 \pm 59.39^{\mathrm{c}, \mathrm{d}}$ \\
C7 & $1362.59 \pm 18.57^{\mathrm{a}}$ & $1140.01 \pm 39.86^{\mathrm{a}}$ & $603.14 \pm 39.86^{\mathrm{a}}$ \\
C8 & $1714.81 \pm 60.56^{\mathrm{b}}$ & $2016.59 \pm 147.17^{\mathrm{b}}$ & $6502.60 \pm 638.78^{\mathrm{e}}$ \\
\hline \multicolumn{4}{c}{ Different letters in the same column mean statistically significant differences $(p \leq 0.05)}$.
\end{tabular}

The results obtained in this study were in close agreement with others previously obtained by different authors such as Sampath et al. [39], who obtained similar results in extracts obtained after the fermentation with LAB of viscera of horse mackerel. In another study, Altinelataman et al. [26] found antioxidants at maximum concentrations, between 0.25 and $0.5 \mathrm{mg} / \mathrm{mL}$, in hydrolyzed sea bass. Sae-Leaw et al. [40] and Vázquez et al. [41] also found similar results with broths prepared with hydrolyzed gelatine and fermented byproducts with LAB of hake, grenadier fish, and horse mackerel among others.

Moreover, Raghavan et al. [42] showed an important antioxidant activity in tilapia hydrolysates. In addition, there are more studies that found antioxidant peptides in the skin of blacktip shark, blue mussel protein, cod protein, Trichiurus japonicus protein, skate skin, and oysters [43-45].

\subsection{Correlations between Phenolic Acids and Total Antioxidant Capacity}

In order to know the correlations between the different antioxidant compounds studied and the total antioxidant capacity (TAC), Pearson's test was performed. Significant positive correlations $(p \leq 0.05)$ were found between benzoic acid and TAC $(r=0.2967)$ in fermented MBG. On the other hand, the correlation between DL-3-phenyllactic acid and TAC was also significant $(p \leq 0.05)$, but it showed a negative correlation $(r=-0.2744)$.

However, when the existing correlations in phenolic acids and TAC of the fermented WBG were evaluated, the different behavior was evidenced. There was no significant correlation between benzoic 
acid and TAC $(r=0.1099 ; p>0.05)$. Nevertheless, there was significant $(p \leq 0.0001)$ and positive correlation between DL-3-phenyllactic acid and TAC $(r=0.5793)$. The difference between the results obtained in both samples may be due to the difference in the composition of the broths.

Although no studies have been found that relate the presence of phenolic acids with antioxidant activity in sea bass byproducts, correlations were observed between phenolic compounds and antioxidant capacity in other marine and vegetable food products (e.g., Laminaria and Porphyra algae) [17,46-48].

\section{Conclusions}

In conclusion, it has been shown that the fermentation of fish byproducts with lactic acid bacteria (LAB) is a useful tool for obtaining antioxidant compounds. As it has been seen, there is a strong positive correlation between DL-3-phenyllactic acid and the total antioxidant capacity. In addition, DL-3-phenyllactic acid is obtained as a result of the fermentation of fish byproducts, which is an economical, clean, and environmentally friendly process. For all these reasons, the fermentation of fish byproducts can be a good strategy for the reduction of fish byproducts through the valorization of them, contributing to achieving sustainable development.

Author Contributions: F.J.B. and G.M. conceived and designed the study; F.J.M.-Q., A.T., A.P., and C.L. performed the experiments; F.J.M.-Q., A.T., and F.J.B. wrote the manuscript; M.-J.R., P.T., and F.J.B. supervised the study and reviewed the manuscript. All authors have read and approved the final manuscript.

Funding: This research was funded by BBI-JU through the H2020 Project AQUABIOPROFIT 'Aquaculture and agriculture biomass side stream proteins and bioactives for feed, fitness and health-promoting nutritional supplements' (Grant agreement no. 790956).

Conflicts of Interest: The authors declare no conflict of interest.

\section{References}

1. The State of World Fisheries and Aquaculture 2018: Meeting the Sustainable Development Goals. Available online: http://www.fao.org/3/i9540en/i9540en.pdf (accessed on 14 March 2020).

2. Olsen, R.L.; Toppe, J.; Karunasagar, I. Challenges and realistic opportunities in the use of by-products from processing of fish and shellfish. Trends Food Sci. Technol. 2014, 36, 144-151. [CrossRef]

3. Iñarra, B.; Bald, C.; Martín, D.S.; Orive, M.; Cebrián, M.; Zufía, J. Guía para la valorización de subproductos de la acuicultura. Available online: https://www.azti.es/wp-content/uploads/2018/12/AZTI_ guia_VALACU1101218online.pdf (accessed on 14 March 2020).

4. Ideia, P.; Pinto, J.; Ferreira, R.; Figueiredo, L.; Spínola, V.; Castilho, P.C. Fish processing industry residues: A review of valuable products extraction and characterization methods. Waste Biomass Valorization 2019. [CrossRef]

5. Al Khawli, F.; Pateiro, M.; Domínguez, R.; Lorenzo, J.M.; Gullón, P.; Kousoulaki, K.; Ferrer, E.; Berrada, H.; Barba, F.J. Innovative green technologies of intensification for valorization of seafood and their by-products. Mar. Drugs 2019, 17, 689. [CrossRef] [PubMed]

6. Gómez, B.; Munekata, P.E.S.; Gavahian, M.; Barba, F.J.; Martí-Quijal, F.J.; Bolumar, T.; Campagnol, P.C.B.; Tomasevic, I.; Lorenzo, J.M. Application of pulsed electric fields in meat and fish processing industries: An overview. Food Res. Int. 2019, 123, 95-105. [CrossRef] [PubMed]

7. Hui, Y.H.; Özgül Evranuz, E. Handbook of Vegetable Preservation and Processing, 2nd ed.; M. Dekker: New York, NY, USA, 2004.

8. Marti-Quijal, F.J.; Remize, F.; Meca, G.; Ferrer, E.; Ruiz, M.-J.; Barba, F.J. Fermentation in fish and by-products processing: An overview of current research and future prospects. Curr. Opin. Food Sci. 2020, 31, 9-16. [CrossRef]

9. Carr, F.J; Chill, D.; Maida, N. The lactic acid bacteria: A literature survey. Crit. Rev. Microbiol. 2002, 28, 281-370. [CrossRef] [PubMed]

10. Vásquez M, S.M.; Suárez M, H.; Zapata B, S. Utilización de sustancias antimicrobianas producidas por bacterias acido lácticas en la conservación de la carne. Rev. Chil. Nutr. 2009, 36, 64-71.

11. Ringø, E.; Gatesoupe, F.-J. Lactic acid bacteria in fish: A review. Aquaculture 1998, 160, 177-203. [CrossRef] 
12. Di Cagno, R.; Cardinali, G.; Minervini, G.; Antonielli, L.; Rizzello, C.G.; Ricciuti, P.; Gobbetti, M. Taxonomic structure of the yeasts and lactic acid bacteria microbiota of pineapple (Ananas comosus L. Merr.) and use of autochthonous starters for minimally processing. Food Microbiol. 2010, 27, 381-389. [CrossRef]

13. Mulero Cánovas, J.; Zafrilla Rentero, P.; Martínez-Cachá Martínez, A.; Leal Hernández, M.; Abellán Alemán, J. Péptidos bioactivos. Clín. Investig. Arterioscler. 2011, 23, 219-227. [CrossRef]

14. Chaves-López, C.; Serio, A.; Paparella, A.; Martuscelli, M.; Corsetti, A.; Tofalo, R.; Suzzi, G. Impact of microbial cultures on proteolysis and release of bioactive peptides in fermented milk. Food Microbiol. 2014, 42,117-121. [CrossRef] [PubMed]

15. González-olivares, L.; Jimenez-Guzman, J.; Cruz, A.; Rodríguez-Serrano, G.; Gómez-Ruiz, L.; García-Garibay, M. Bioactive peptides released by lactic acid bacteria in commercial fermented milks. Rev. Mex. Ing. Quim. 2011, 10, 179-188.

16. Broberg, A.; Jacobsson, K.; Strom, K.; Schnurer, J. Metabolite Profiles of lactic acid bacteria in grass silage. Appl. Environ. Microbiol. 2007, 73, 5547-5552. [CrossRef] [PubMed]

17. Jiménez Escrig, A.; Jiménez Jiménez, I.; Pulido, R.; Saura Calixto, F. Antioxidant activity of fresh and processed edible seaweeds. J. Sci. Food Agric. 2001, 81, 530-534. [CrossRef]

18. Vandeputte, M.; Gagnaire, P.-A.; Allal, F. The European sea bass: A key marine fish model in the wild and in aquaculture. Anim. Genet. 2019, 50, 195-206. [CrossRef]

19. Arechavala-Lopez, P.; Toledo-Guedes, K.; Izquierdo-Gomez, D.; Šegvić-Bubić, T.; Sanchez-Jerez, P. Implications of sea bream and sea bass escapes for sustainable aquaculture management: A review of interactions, risks and consequences. Rev. Fish. Sci. Aquac. 2018, 26, 214-234. [CrossRef]

20. Messina, C.M.; Renda, G.; La Barbera, L.; Santulli, A. By-products of farmed European sea bass (Dicentrarchus labrax L.) as a potential source of n-3 PUFA. Biologia 2013, 68, 288-293. [CrossRef]

21. Özyurt, G.; Özkütük, A.S.; Uçar, Y.; Durmuş, M.; Özoğul, Y. Fatty acid composition and oxidative stability of oils recovered from acid silage and bacterial fermentation of fish (Sea bass - Dicentrarchus labrax) by-products. Int. J. Food Sci. Technol. 2018, 53, 1255-1261. [CrossRef]

22. Astuti, M.P. Isolation, characterization, and identification lactic acid bacteria from chicken waste faeces that potential as probiotics. Int. J. Sci. Res. Publ. 2016, 6, 180-191.

23. Axelsson, L. Lactic acid bacteria: Classification and physiology. In Lactic Acid Bacteria Microbiological and Functional Aspects, Third Edition: Revised and Expanded; CRC Press: Boca Raton, FL, USA, 2004; pp. 1-66.

24. Chenoll, E.; Moreno, I.; Sánchez, M.; Garcia-Grau, I.; Silva, Á.; González-Monfort, M.; Genovés, S.; Vilella, F.; Seco-Durban, C.; Simón, C.; et al. Selection of new probiotics for endometrial health. Front. Cell. Infect. Microbiol. 2019, 9, 114-126. [CrossRef]

25. BLAST: Basic Local Alignment Search Tool. Available online: https://blast.ncbi.nlm.nih.gov/Blast.cgi (accessed on 14 March 2020).

26. Altınelataman, C.; Koroleva, O.; Fedorova, T.; Torkova, A.; Lisitskaya, K.; Tsentalovich, M.; Kononikhin, A.; Popov, I.; Vasina, D.; Kovalyov, L.; et al. An in vitro and in silico study on the antioxidant and cell culture-based study on the chemoprotective activities of fish muscle protein hydrolysates obtained from European seabass and gilthead seabream. Food Chem. 2019, 271, 724-732. [CrossRef] [PubMed]

27. El-Ghaish, S.; Dalgalarrondo, M.; Choiset, Y.; Sitohy, M.; Ivanova, I.; Haertlé, T.; Chobert, J.-M. Screening of strains of Lactococci isolated from Egyptian dairy products for their proteolytic activity. Food Chem. 2010, 120, 758-764. [CrossRef]

28. Denardi-Souza, T.; Luz, C.; Mañes, J.; Badiale-Furlong, E.; Meca, G. Antifungal effect of phenolic extract of fermented rice bran with Rhizopus oryzae and its potential use in loaf bread shelf life extension. J. Sci. Food Agric. 2018, 98, 5011-5018. [CrossRef] [PubMed]

29. Re, R.; Pellegrini, N.; Proteggente, A.; Pannala, A.; Yang, M.; Rice-Evans, C. Antioxidant activity applying an improved ABTS radical cation decolorization assay. Free Radic. Biol. Med. 1999, 26, 1231-1237. [CrossRef]

30. Ringø, E.; Hoseinifar, S.H.; Ghosh, K.; Van Doan, H.; Beck, B.R.; Song, S.K. Lactic acid bacteria in finfish-An update. Front. Microbiol. 2018, 9, 1818-1854. [CrossRef] [PubMed]

31. Egerton, S.; Culloty, S.; Whooley, J.; Stanton, C.; Ross, R.P. The gut microbiota of marine fish. Front. Microbiol. 2018, 9, 873-889. [CrossRef] [PubMed]

32. Bajpai, V.K.; Han, J.-H.; Nam, G.-J.; Majumder, R.; Park, C.; Lim, J.; Paek, W.K.; Rather, I.A.; Park, Y.-H. Characterization and pharmacological potential of Lactobacillus sakei 111 isolated from fresh water fish Zacco koreanus. Daru 2016, 24, 8-19. [CrossRef] 
33. Lavermicocca, P.; Valerio, F.; Visconti, A. Antifungal activity of phenyllactic acid against molds isolated from bakery products. Appl. Environ. Microbiol. 2003, 69, 634-640. [CrossRef]

34. Lau, A.-S.-Y.; Liong, M.-T. Lactic acid bacteria and bifidobacteria inhibited Staphylococcus epidermidis. Wounds Compend. Clin. Res. Pract. 2014, 26, 121-131.

35. Urbiene, S.; Leskauskaite, D. Formation of some organic acids during fermentation of milk. Pol. J. Food Nutr. Sci. 2006, 15, 277-281.

36. Quattrini, M.; Bernardi, C.; Stuknytè, M.; Masotti, F.; Passera, A.; Ricci, G.; Vallone, L.; De Noni, I.; Brasca, M.; Fortina, M.G. Functional characterization of Lactobacillus plantarum ITEM 17215: A potential biocontrol agent of fungi with plant growth promoting traits, able to enhance the nutritional value of cereal products. Food Res. Int. 2018, 106, 936-944. [CrossRef] [PubMed]

37. Ramos, A.N.; Sesto Cabral, M.E.; Arena, M.E.; Arrighi, C.F.; Arroyo Aguilar, A.A.; Valdéz, J.C. Compounds from Lactobacillus plantarum culture supernatants with potential pro-healing and anti-pathogenic properties in skin chronic wounds. Pharm. Biol. 2015, 53, 350-358. [CrossRef] [PubMed]

38. Yu, H.-S.; Lee, N.-K.; Jeon, H.-L.; Eom, S.J.; Yoo, M.-Y.; Lim, S.-D.; Paik, H.-D. Benzoic acid production with respect to starter culture and incubation temperature during yogurt fermentation using response surface methodology. Korean J. Food Sci. Anim. Resour. 2016, 36, 427-434. [CrossRef] [PubMed]

39. Sampath Kumar, N.S.; Nazeer, R.A.; Jaiganesh, R. Purification and biochemical characterization of antioxidant peptide from horse mackerel (Magalaspis cordyla) viscera protein. Peptides 2011, 32, 1496-1501. [CrossRef]

40. Sae-Leaw, T.; Karnjanapratum, S.; O'Callaghan, Y.C.; O’Keeffe, M.B.; FitzGerald, R.J.; O'Brien, N.M.; Benjakul, S. Purification and identification of antioxidant peptides from gelatin hydrolysate of seabass skin. J. Food Biochem. 2017, 41, e12350. [CrossRef]

41. Vázquez, J.A.; Meduíña, A.; Durán, A.I.; Nogueira, M.; Fernández-Compás, A.; Pérez-Martín, R.I.; Rodríguez-Amado, I. Production of valuable compounds and bioactive metabolites from by-products of fish discards using bacterial fermentation production of valuable compounds and bioactive metabolites from by-products of fish discards using chemical processing, enzymatic hydrolysis, and bacterial fermentation. Mar. Drugs 2019, 17, 139-153.

42. Raghavan, S.; Kristinsson, H.G.; Leeuwenburgh, C. Radical scavenging and reducing ability of tilapia (Oreochromis niloticus) protein hydrolysates. J. Agric. Food Chem. 2008, 56, 10359-10367. [CrossRef]

43. Yang, X.-R.; Zhang, L.; Ding, D.-G.; Chi, C.-F.; Wang, B.; Huo, J.-C. Preparation, identification, and activity evaluation of eight antioxidant peptides from protein hydrolysate of hairtail (Trichiurus japonicas) muscle. Mar. Drugs 2019, 17, 23. [CrossRef]

44. Suarez-Jimenez, G.-M.; Burgos-Hernandez, A.; Ezquerra-Brauer, J.-M. Bioactive peptides and depsipeptides with anticancer potential: Sources from marine animals. Mar. Drugs 2012, 10, 963-986. [CrossRef]

45. Wu, R.; Chen, L.; Liu, D.; Huang, J.; Zhang, J.; Xiao, X.; Lei, M.; Chen, Y.; He, H. Preparation of antioxidant peptides from salmon byproducts with bacterial extracellular proteases. Mar. Drugs 2017, 15, 4. [CrossRef]

46. Shen, S.; Wang, J.; Chen, X.; Liu, T.; Zhuo, Q.; Zhang, S.-Q. Evaluation of cellular antioxidant components of honeys using UPLC-MS/MS and HPLC-FLD based on the quantitative composition-activity relationship. Food Chem. 2019, 293, 169-177. [CrossRef] [PubMed]

47. Yang, X.-J.; Dang, B.; Fan, M.-T. Free and bound phenolic compound content and antioxidant activity of different cultivated blue highland barley varieties from the Qinghai-Tibet Plateau. Molecules 2018, 23, 879-898. [CrossRef] [PubMed]

48. Salas-Pérez, L.; Gaucín-Delgado, J.M.; Preciado-Rangel, P.; Fortis-Hernández, M.; Valenzuela-García, J.R.; Ayala-Garay, A.V. Benzoic acid effect in the antioxidant capacity of wheat sprouts. Rev. Mex. De Cienc. Agric. 2016, 3397-3404.

(C) 2020 by the authors. Licensee MDPI, Basel, Switzerland. This article is an open access article distributed under the terms and conditions of the Creative Commons Attribution (CC BY) license (http://creativecommons.org/licenses/by/4.0/). 